\title{
Cellular toxicity and biological activities of honey bee (Apis mellifera L.) venom
}

\author{
Yaşar Gülmez, Ali Aydın, İlyas Can, Şaban Tekin, Ercan Cacan
}

\begin{abstract}
Bee venom (BV) has been suggested as an apitherapy tool to be considered for various diseases including cancer. However, the mechanisms action of BV and its toxicity on tumorigenic and nontumorigenic cells are poorly understood. Here, we investigated the antiproliferative, cytotoxic and antibacterial activities of honey bee (Apis mellifera L.) venom on nontumorigenic cells, several tumor cell lines and multidrug resistant human pathogens (MDRP) such as Extended Spectrum Beta-Lactamases producing Escherichia coli and Vancomycinresistant Enterococcus Enterococcus faecium. BV treatment showed significant antiproliferative, cytotoxic and antibacterial
\end{abstract}

activities. Our results suggest that BV is highly toxic not only to cancer cell lines but also to nontumorigenic cell line as well. We also investigated the mechanism action of BV, which caused a cleavage of genomic DNA and inhibition of cell migration, indicating induction of apoptosis. Immunohistochemistry studies demonstrated that BV decreased the expression of Bcl-2 and P16. BV showed antimicrobial activity against several tested-MDRP. Our results indicate that clinic consideration of $\mathrm{BV}$ for the treatment of malignancy needs to be re-evaluated due to its cytotoxicity against normal cells.

Keywords: Apis mellifera bee venom; Antiproliferative activity; Antibacterial activity; Cytotoxic activity
Yaşar Gülmez, İlyas Can

Department of Biology, Gaziosmanpasa University, 60250 Tokat, Turkey.

Ali Aydın, Şaban Tekin, Ercan Cacan

Department of Molecular Biology and Genetics, Gaziosmanpasa University, 60250 Tokat, Turkey.

Şaban Tekin

TUBİTAK MAM Genetic Engineering and Biotechnology Institute, Kocaeli, Turkey.

Corresponding Author:

Yaşar Gülmez

e-mail:yasar_gulmez@yahoo.com,yasar.gulmez@gop.edu.tr

Submitted / Gönderilme: 23.10.2016 Revised / Düzeltme: 11.01.2017 Accepted / Kabul: 12.01 .2017

\section{Introduction}

Honeybee venom (BV) has been traditionally used with the hope to cure several diseases such as cancer, arthritis, and rheumatism (1-5). BV composed of many complex substances such as peptides (melittin, apamin, secapin, tertiapin, adolapin, and mast cell degranulating peptide), enzymes (phospholipase $A_{2}$, hyaluronidase, acid phosphomonoesterase, lysophospholipase), active amines (histamine, dopamine, norepinephrine, serotonin), and other components, which have a comprehensive pharmaceutical properties to some extent $(1,6)$. Recent studies have revealed that the BV increases cytoplasmic $\mathrm{Ca}^{2+}$ and reactive oxygen species (ROS) and decreases mitochondrial membrane potential, which enhance the levels of caspase-3, PARP, FAS, p53, p21 and Bax, and reduces level of Bcl-2. The effects of BV on the DNA fragmentation are due to its ability to enhance the caspase- 8 and caspase- 9 through promoting caspase-3 activation (7-10). Melittin, the principal active component of $\mathrm{BV}$, alone induced apoptosis in human leukemic U937 cells through reducing Bcl-2, NF-kB and increasing caspase-3, $(11,12)$. Other studies showed that 
BV inhibited cell invasion and migration by suppressing the MMP-9 activity and expression through inhibiting of NF- $\kappa B$ via $\mathrm{p} 38 \mathrm{MAPK}$ and JNK signaling pathways in PMA-induced MCF-7 cells (13), and by suppressing MMP-2 and MMP-9 activity in mouse skin fibroblast and myelogenous leukemia cell lines (14). A recent study showed that BV and melittin substantially decelerate capability of invasion and migration of breast cancer cells via inhibiting the EGF-induced MMP-9 expression by blocking the NF-kB and PI3K/Akt/mTOR pathway (15). The protein, Ki-67, was suppressed by BV in SMMC-7721 cells (16). It is also known that BV treatment increases ROS levels, and then, as a response, it causes rising expression levels of GST, Zn-SOD, Cu/Zn-SOD and catalase in MCF7 cells (9). Earlier studies above mentioned showed that the bee venom contains various groups of substances which exhibit antiproliferative activity against various tumor cells. However, antibacterial activity and mechanism of action of BV on MRP remain unknown. The aim of the present study was to determine antiproliferative, cytotoxic, antibacterial activities of BV and its mechanism of action on tumorigenic and nontumorigenic cells.

\section{Materials and Methods}

\section{Venom preparation}

Adult worker honeybee samples were randomly selected from 50 hives in the apiary at Gaziosmanpasa University, Tokat, Turkey. Venom sacs of the bees were dissected using a Leica S4E stereo microscope, and they were placed in micro centrifuge tubes including $100 \mu \mathrm{L}$ DPBS and then carefully crushed with a sterile pestle to release its contents. The crushed venom sacs were then spun at $10.000 \mathrm{~g}$ for $1 \mathrm{~min}$ and the supernatant was collected. The supernatant lyophilized and used as venom. The lyophilized venom was suspended in DPBS at $20 \mathrm{mg} / \mathrm{mL}$ concentration to prepare the stock solution.

\section{Cell Culture}

The anticancer potential of $\mathrm{BV}$ was investigated on tumorigenic C6, HT29, and HeLa cells and nontumorigenic Vero cells. C6, HT29, HeLa, and Vero cell lines were maintained in Dulbecco's modified eagle's medium (DMEM, Sigma) supplemented with $10 \%(\mathrm{v} / \mathrm{v})$ fetal bovine serum (Sigma, Germany) and PenStrep solution (10000 U/10 mg) (Sigma, Germany) (ATCC, American Type Culture Collection).

\section{Cell proliferation assay}

The antiproliferative activity of BV against indicated cell lines was tested by cell proliferation assay by using BrdU Cell Proliferation ELISA kit (Roche). A cell suspension containing approximately $5 \times 10^{3}$ cells in $100 \mu \mathrm{L}$ was pipetted into the wells of 96-well cell culture plates (COSTAR, Corning, USA). The cells were treated with native and heat treated-BV dissolved in sterile DPBS, and control drug, 5 Fluorouracil (5FU) dissolved in sterile DPBS at final concentrations of $2.4,4.8,9.6,14.4,19.2,24.0,36.0$, and $48.0 \mu \mathrm{g} / \mathrm{mL}$. The final volume of the wells was adjusted to $200 \mu \mathrm{L}$ by supplemented DMEM and cells were incubated at $37{ }^{\circ} \mathrm{C}$ with $5 \% \mathrm{CO}_{2}$ for overnight. The rest of the proliferation assay was performed as described as in Aydin, et al. (17).

\section{Calculation of $\mathrm{IC}_{\mathbf{5 0}}$ and percent inhibition}

$\mathrm{IC}_{50}$ represents the concentration of an agent that is required for $50 \%$ inhibition in vitro. The half maximal inhibitory concentration $\left(\mathrm{IC}_{50}\right)$ of the test and control compounds was calculated using XLfit5 software (IDBS) and expressed in $\mu \mathrm{g} / \mathrm{mL}$ at $95 \%$ confidence intervals. The proliferation assay results were reported as the percent inhibition of the test and control substances. The percent inhibition was calculated according to the following formula: $\%$ inhibition $=[1$ (Absorbance of Treatments / Absorbance of Controls) ' 100].

\section{Cytotoxicity assay}

The cytotoxicity of BV and 5FU on C6, HT29, HeLa, and Vero cells was determined through a Lactate Dehydrogenase (LDH) Cytotoxicity Detection Kit (Roche, USA) according to manufacturer's instructions. Approximately 5 ' $10^{3}$ cells in $100 \mu \mathrm{L}$ were seeded into 96-well microtiter plates as triplicates and treated with 2.4 , 4.8, 9.6, 14.4, 19.2, 24.0, 36.0, and $48.0 \mu \mathrm{g} / \mathrm{mL}$ concentrations of bee venom at $37^{\circ} \mathrm{C}$ with $5 \%$ $\mathrm{CO}_{2}$ overnight. $\mathrm{LDH}$ activity was determined by measuring absorbance at 492 - $630 \mathrm{~nm}$ using a microplate reader.

\section{Detection of apoptosis}

In vitro detection of apoptosis was assessed on HT29 cells using a terminal deoxynucleotidyl transferase dUTP nick end labeling (TUNEL) assay kit (Roche, Germany) according to the manufacturer's protocol. The cells (30.000/well) were placed in a poly-L-lysine covered chamber slide and treated with the $\mathrm{IC}_{50}$ concentrations of $\mathrm{BV}$ at $37^{\circ} \mathrm{C}$ for 24 hours. DNase-I treatment was used as positive control. Terminal 
deoxynucleotidyl transferase was not added for negative controls. The rest of the assay was performed as described in Aydin, et al. (17). Fluorescent signal was visualized by a Leica fluorescent microscope (Leica DM IL LED fluo, Germany).

\section{DNA fragmentation assay}

A DNA fragmentation activity of the BV was measured by using DNA laddering assay according to the method of Gong et al. (18) with some modifications as described in Aydin, et al. (17).

\section{Cell imaging}

Cells were seeded in 96-well plates at a density of 5.000 cells per well and allowed $24 \mathrm{~h}$ for attachment. Using previously established IC50 doses of BV treatment was performed for $24 \mathrm{~h}$, during which morphology changes were assessed by phase contrast microscopy. Images of vehicle (DPBS) and BV treated cells were taken at the end of the experimental period using a digital camera attached inverted microscope (Leica IL10, Germany).

\section{Wound-closure assay}

Briefly, a culture insert, a culture insert (Ibidi GmbH, Germany) consists of two reservoirs separated by a 500 $\mu \mathrm{m}$ thick wall, was placed on a $35-\mathrm{mm}$ sterile petri dish, and an equal number of HeLa cells $\left(3.5 \times 10^{4}\right.$ cells in $70 \mu \mathrm{L}$ DMEM medium) were seeded into the two reservoirs of the same insert and allowed to grow to $90-95 \%$ confluence, in order to generate a $500 \mu \mathrm{m}$ gap between two cell populations. Following cell growth, the insert was gently removed and $2 \mathrm{~mL}$ of cell culture medium was added, and then treated with $\mathrm{IC}_{30}$ concentrations of BV shortly after an incubated overnight at $37^{\circ} \mathrm{C}$ with $5 \%$ $\mathrm{CO}_{2}$. The speed of cell closure was photographed 0,1 and 2 days after incubation using a phase contrast inverted microscope (Leica DMIL, Germany) until complete cell closure was observed in the untreated control. We further investigated whether cell migration inhibitory effect of BV treatment on HeLa cells was reversible by re-culturing BV treated cells in culture medium without BV. Briefly, HeLa cells treated with BV for 3 days in wound-closure assay wells, culture medium replaced with fresh culture medium without BV and incubated for additional 3 days. Eventually, change in migration of cells was observed by phase-contrast microscopy.

\section{DNA topoisomerase I inhibition assay}

The DNA topoisomerase I inhibitory activity following BV treatment was evaluated using a cell-free topoisomerase I assay kit (TopoGen, USA). The principle of the assay is to measure the conversion of supercoiled pHOT1 plasmid DNA to its relaxed form in the presence of DNA topoisomerase I alone and with BV. In brief, $20 \mu \mathrm{L}$ of a reaction mixture containing $0.25 \mu \mathrm{g} / \mu \mathrm{L}$ of plasmid pHOT1 DNA in relaxation buffer was incubated with $2 \mathrm{U}$ recombinant human topoisomerase I enzyme in the presence of various concentrations of $\mathrm{BV}$, or camptothecin as positive control. The reactions were carried out at $37^{\circ} \mathrm{C}$ for $30 \mathrm{~min}$ and then terminated by the addition of stop solution. After the termination, the sample was analyzed using $1 \%$ agarose gel at $4 \mathrm{~V} / \mathrm{cm}$ for $60 \mathrm{~min}$. After electrophoresis, DNA bands were stained with ethidium bromide (EtdBr) $(1 \mathrm{mg} / \mathrm{mL})$ solution and visualized through a gel imaging system (UVP BioSpectrum, Germany).

\section{Immunohistochemistry (IHC)}

The effect of BV treatment on the localization and expression of antigens was determined by using an immunohistochemistry detection kit (Ventana, USA). Immunohistochemistry was performed according to manufacturer's procedure using antibodies and reagents from the kit. Accordingly, HT29 and HeLa cell lines (15.000 cells/well) were placed in a polyL-lysine covered chamber slide. The cells were treated with $\mathrm{IC}_{30}$ concentration of BV and incubated for $24 \mathrm{~h}$. BV mock treatment was used as negative control. The rest of the assay was performed as described in manufacturer's instructions. IHC was performed using Bcl-2 (clone 124), CK7 (clone OV-TL 12/30), CK20 (clone Ks20.8), pan-CK (clone AE1/ AE3\&PCK26), Ki-67 (clone SP6), P16 (clone E6H4), P53 (clone D07), and Cyclin D1 (clone SP4). For the HeLa and the HT29 cell lines, the number of positive and negative cells was counted in five zones. This procedure was repeated three times for each protein stained slide. The slides were scored staining intensity score rated as follows: no staining ( 0 , no stained cells or $<5 \%$ positive cells), weak staining $(1+, 5-24 \%$ positive cells), moderate staining (2+, $25-49 \%$ positive cells), and strong staining $(3+,>50 \%$ positive cells). A score of $2+$ or $3+$ was considered positive for relevant expression while a score of 0 or $1+$ was considered negative.

\section{Antimicrobial activity assay}

The multidrug resistant (MDRP), extended-spectrum beta-lactamase (ESBL) producing Escherichia coli and 
vancomycin-resistant Enterococcus faecium (VRE), were kindly provided by Dr. Pervin Özlem Balcı and evaluated for the following 16 drugs: Ampicillin/Sulbactam, Cefazolin, Gentamicin, Ceftazidime, Piperacillin/Tazobactam, Imipenem, Cefotaxime/Clavulanate, Ceftazidime/ Clavulanate, Ceftriaxone/Clavulanate, Penicillin, Ampicillin, Erythromycin, Clindamycin, Vancomycin, Daptomycini, Linezolid in present or absent BV. The microdilution assay was performed repeated on three separate days with the Phoenix System recommended procedures. Inoculum was prepared for Phoenix for each test strain to achieve the CLSI (19) recommended density of approximately $5 \times 10^{5}$ CFU/mL in Phoenix AST broth tube. Then, the AST broth tube treated with $48.0 \mu \mathrm{g} / \mathrm{mL}$ concentrations of bee venom. Finally, the AST tube inoculum into the fill port on the AST side of the panel was poured. The Phoenix panels (NMIC/ ID-99 and PMIC/ID-70) that are ready to use were loaded onto the Phoenix 100 system and samples were processed according to the manufacturer's instructions. Antibacterial activity assays were also carried out by the disc-diffusion method using $100 \mathrm{~mL}$ of suspension containing $10^{8} \mathrm{CFU}$ per $\mathrm{mL}$ of bacteria on nutrient agar. The antibiotic discs were impregnated with $20 \mu \mathrm{L}$ of the BV ( $48 \mu \mathrm{g} / \mathrm{mL}$ per disc) and placed on the inoculated agar. The inoculated plates were incubated at $36^{\circ} \mathrm{C}$ for $24 \mathrm{~h}$ for bacterial strains. Antibacterial activity was evaluated by measuring the zone of inhibition against the test organisms.

\section{Statistical analysis}

The statistical significance of differences was determined by one-way analysis of variance (one-way ANOVA) tests. SPSS for Windows was used for statistical analyses. The results are reported as the mean values \pm SEM of three independent assays, and differences between groups were considered to be significant at $\mathrm{P}<0.05$.

\section{Results}

\section{Antiproliferative activity of BV against HeLa, HT29, C6 and} Vero cell lines

BV treatment showed significantly $(\mathrm{P}<0.05)$ higher antiproliferative activity than $5 \mathrm{FU}$ against all cell lines tested (Figure 1A). The antiproliferative activity of BV was dosedependent. In addition, as illustrated in Figure 1A, heattreatment $\left(90{ }^{\circ} \mathrm{C}\right.$ for $\left.15 \mathrm{~min}\right)$ was significantly reduced antiproliferative potential of $\mathrm{BV}$, indicating the protein fraction of venom may be responsible for antiproliferative activity of BV. The $\mathrm{IC}_{50}$ values of BV calculated using ELISA data were approximately $20.58 \mu \mathrm{g} / \mathrm{mL}$ for HeLa cells, 25.26 $\mu \mathrm{g} / \mathrm{mL}$ for C6 cells, $30.07 \mu \mathrm{g} / \mathrm{mL}$ for HT29 cells, and 19.71 $\mu \mathrm{g} / \mathrm{mL}$ for Vero cells. These data indicate that BV has similar activity on both tumorigenic and nontumorigenic cell lines.

Cytotoxic Activity of BV against HeLa, HT29, C6 and Vero cell lines

HeLa, HT29, C6 and Vero cell lines were treated with BV at concentrations of $2.4,4.8,9.6,14.4,19.2,24.0,36.0$, and $48.0 \mu \mathrm{g} / \mathrm{mL}$ for 24 hours (Figure 1B). BV displayed high cytotoxicity against all cells tested and it was dose dependent. Here, we also emphasized that BV were found to have low cytotoxic values in comparison to other similar venoms such as Sphex flavipennis (Hymenoptera: Sphecidae) solitary wasp venom with $\% 98$ cytotoxicity at $\mathrm{IC}_{50}$ concentration (data not shown).

\section{Apoptotic potential of $B V$}

We performed a TUNEL assay to determine whether the BVinduced inhibition of cell proliferation was associated with cellular apoptosis. As illustrated in Figure 1C, BV (30.07 $\mu \mathrm{g} / \mathrm{mL}, \mathrm{IC}_{50}$ ) and DNase I (PC, positive control) treated cells displayed a higher percentage of TUNEL-positive apoptotic cell nuclei $(\mathrm{P}<0.05)$, indicating the nicked DNA, whereas the DPBS control was TUNEL-negative. It is very interesting that $\mathrm{BV}$ treated cells were found to show more intense light emission than DNase I treated cells. For each concentration $(2.4,4.8,9.6,14.4,19.2,24.0,36.0$, and 48.0 $\mu \mathrm{g} / \mathrm{mL}$ ), the apoptotic index was determined by counting the percentage of TUNEL-positive cells from at least 100 nuclei. The apoptotic index was about $10 \%$ at $\mathrm{IC}_{50}$ concentration. The incidence of TUNEL-positive cell nuclei was higher at high concentrations starting from $\geq 19.2 \mu \mathrm{g} / \mathrm{mL}$.

\section{DNA fragmentation potential of $B V$}

The cells were subjected to various concentrations of BV to further evaluate DNA fragmentation, a hallmark of cell apoptosis. As shown in Figure 1D, BV induced DNA laddering in all cells at $\mathrm{IC}_{90}$ concentration $(47.91 \mu \mathrm{g} / \mathrm{mL}$ for HT29, $46.76 \mu \mathrm{g} / \mathrm{mL}$ for C6, $43.87 \mu \mathrm{g} / \mathrm{mL}$ for HeLa, $48.95 \mu \mathrm{g} /$ $\mathrm{mL}$ for Vero). 


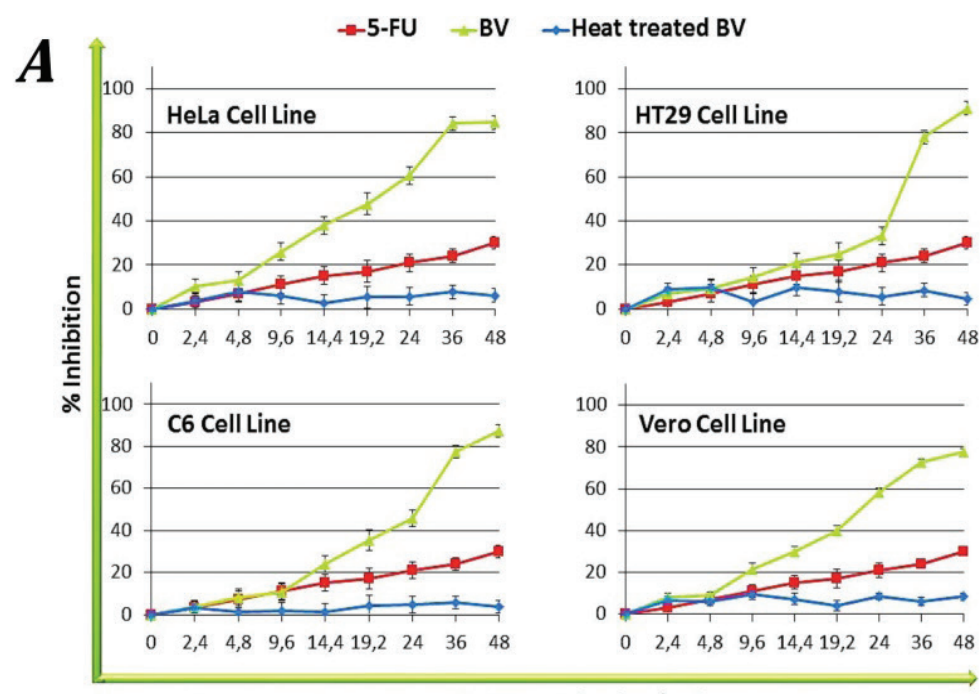

Concentration $(\mu \mathrm{g} / \mathrm{mL})$

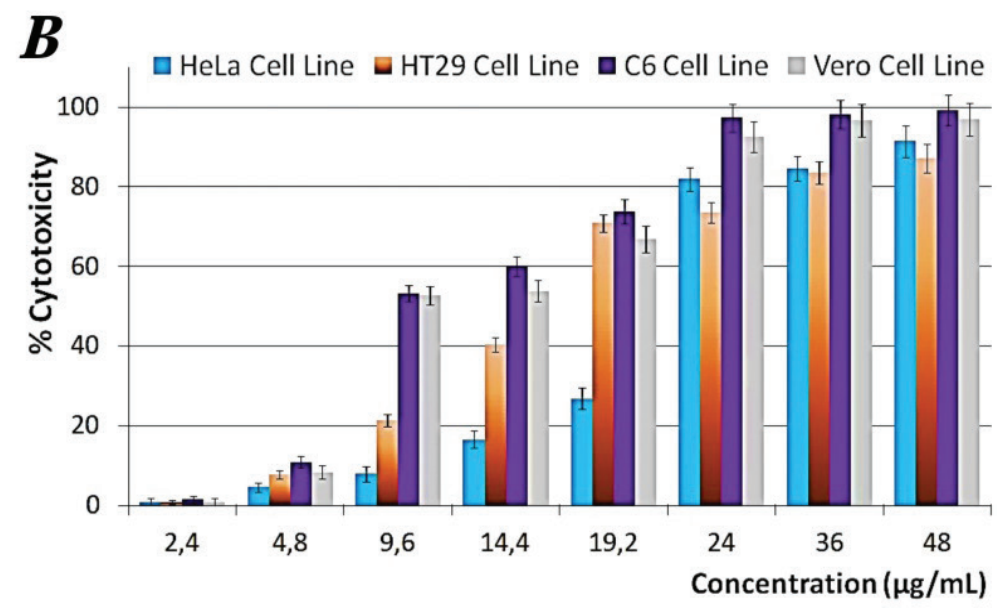

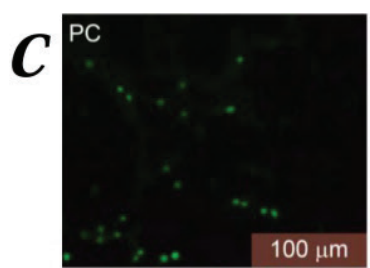
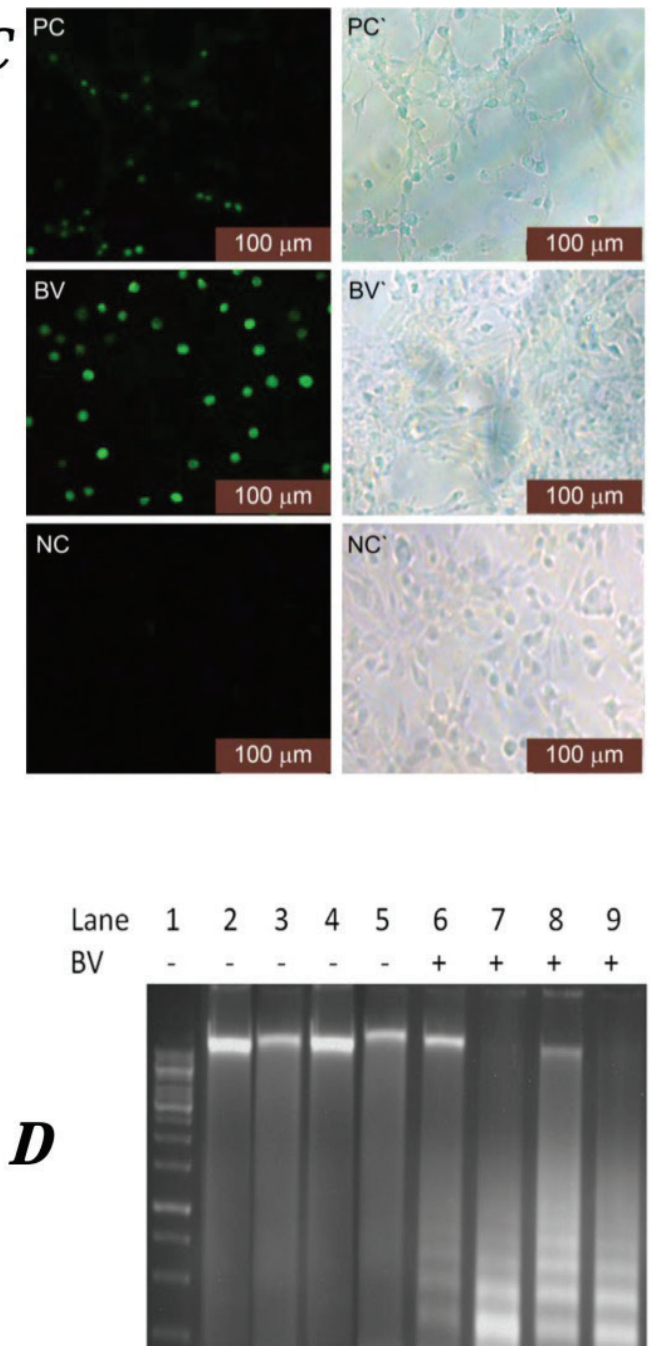

Figure 1. (A) The Antiproliferative activity of BV and positive control compound, 5FU on cells. Percent inhibition was reported as mean values \pm SEM of three independent assays $(\mathrm{P}<0.05)$. Each experiment was repeated at least three times for each cell line. (B) Cytotoxic activity of BV on cells. Percent cytotoxicity was reported as mean values \pm SDs of three independent assays (P $<0.05)$. (C) Fluorescence and phase-contrast images of the HT29 cancer cells treated with BV, DNase I and DPBS after TUNEL assay. TUNEL-positive cell nuclei were observed in brilliant green under fluorescence. (Flourescence/Phase-contrast: PC/PC', positive control; BV/BV', bee venom; NC/NC', negative control). (D) Representative result shows the effects of BV on DNA fragmentation in cancer cell lines. Exponentially growing cells were incubated with $\mathrm{BV}$ at $37^{\circ} \mathrm{C}$ for overnight, DNA isolated and DNA fragmentation was visualized by agarose gel electrophoresis. Lane 1: DNA Marker; Lane 2: C6 Control; Lane 3: HT29 Control; Lane 4: HeLa Control; Lane 5: Vero Control; Lane 6: C6+BV; Lane 7: HT29+BV; Lane 8: HeLa+BV; Lane 9: Vero+BV.

\section{Effect of BV on cell morphology}

The effect of the BV on the morphology of the cells was determined by microscopic observation. The BV treatment was clearly reduced the number of cells comparing to untreated cells. BV treated cell lines showed shrinkage, apoptotic bodies, and atypical shape depending on BV concentration. Severity of changes in cell morphology was very obvious at $\mathrm{IC}_{50}$ that the cells lost fibroblast like appearance, broke up into pieces, degenerate and started to float.

\section{Inhibition of HeLa cell migration by $B V$}

Cell migration inhibitory potential of BV was studied using wound-closure assay. As shown in Figure 2A, BV inhibited cell migration ability of HeLa cells by at $\mathrm{IC}_{30}$ concentration $(12.04 \mu \mathrm{g} / \mathrm{mL})$ as compared to untreated cells. 


\section{DNA Topoisomerase I inhibitory activity of $B V$}

DNA topoisomerase I is a nuclear enzyme that plays essential roles in controlling the topological state of DNA during DNA replication, gene transcription, and cell division. It is also required for cell viability. Therefore, DNA topoisomerase I is an important target of contemporary anticancer agents. As shown in Figure 2B, BV did not inhibit DNA relaxation activity of DNA topoisomerase I at concentrations ranging from 2.4 to $48 \mu \mathrm{g} / \mathrm{mL}$ (Figure 2B). These data suggest that the cytotoxic activity of BV is not through DNA Topoisomerase I inhibitory activity.
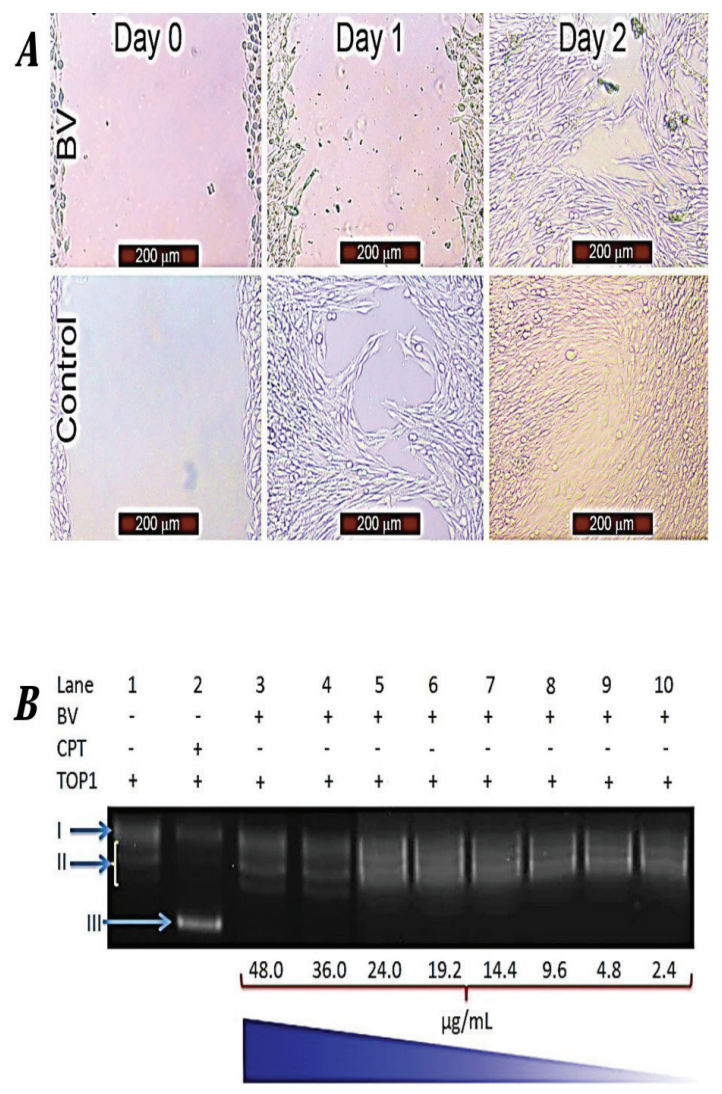

Figure 2. (A) Effect of BV on the migration of the HeLa cell line by wound-closure assay. The closure of the HeLa cell line was photographed 0,1 and 2 days after incubation with $\mathrm{BV}$ at $\mathrm{IC}_{30}$ concentrations using a phase contrast microscope (Leica DMIL, Germany). (B) DNA unwinding analysis with BV. A DNA unwinding assay was performed with $250 \mathrm{ng}$ pHOT-1 supercoiled DNA, 2U TOP1 and various concentrations of BV. The forms of DNA are denoted as I (Nicked DNA), II (Relaxed DNA), and III (Supercoiled DNA). Lane 1 represents the negative control (Supercoiled DNA + TOP1); lane 2 is the positive control (Supercoiled DNA + TOP1 + Camptothecin), and Lanes 3-10 represent BV over an eighty-concentration titration $(2.4,4.8,9.6,14.4,19.2,24.0,36.0$, and $48.0 \mu \mathrm{g} / \mathrm{mL})$.
Immunohistochemistry evaluation of cell treated by $B V$

Immunohistochemistry staining assessment demonstrated that few or no brown signals of Bcl-2 (an important antiapoptotic protein) and p16 (a tumor suppressor protein) was observed in the BV-treated HeLa and HT29 cells compared to the controls (Figure 3). We analyzed the distribution of Ki-67 (marker protein for proliferation) and P53 (a tumor suppressor protein) for HeLa cells and Cyclin D1 (required for cell cycle G1/S transition) and p53 for HT29 cells and observed a discernible reduction of relevant protein staining in the cells treated with $\mathrm{BV}$, whereas the cell of control group displayed significantly more brown staining $(\mathrm{P}<0.05)$. The results were shown in Figure 3, compared with control cells, BV resulted in noticeably reduced the expression of CK20 (a marker protein) and CK7 (a marker protein) $(\mathrm{P}<0.05)$. Interestingly, while $\mathrm{BV}$ increased the expression of pan-CK (AE1/AE3/PCK26, a marker protein) in HeLa cells, it moderately reduced the expression of pan-CK in HT29 cells. Bcl-2 and p16 was weakly expressed by BV treated cells while tumor cells showed intense Ki-67, Cyclin D1, and P53 expression.

\section{Determination of the antibacterial effects of the BV against MDR human pathogens}

It is known that BV is a natural antimicrobial agent with potent activity against most Gram-positive and Gramnegative bacteria. In agreement with this notion, as shown in Table 1, MIC values for ESBL producing Escherichia coli and VRE Enterococcus faecium strains of BV added to the antimicrobial agents at $48.0 \mu \mathrm{g} / \mathrm{mL}$ concentrations showed higher than that of displayed by the antimicrobial agents alone.

The results of the study indicate that BV succeed in antibacterial activity against MDR human pathogen strains, ESBL producing Escherichia coli and VRE Enterococcus faecium. Regardless of this, our findings have been confirmed by using a disc diffusion method (data not shown).

\section{Discussion}

Bee venom (BV) is the most investigated venom among the other arthropod venoms because of its antiproliferative potential (20). In the present study, we have investigated biological activities and mechanism of action of BV. The cell proliferation and cytotoxicity assay results showed that BV has significant antiproliferative and cytotoxic activities not 

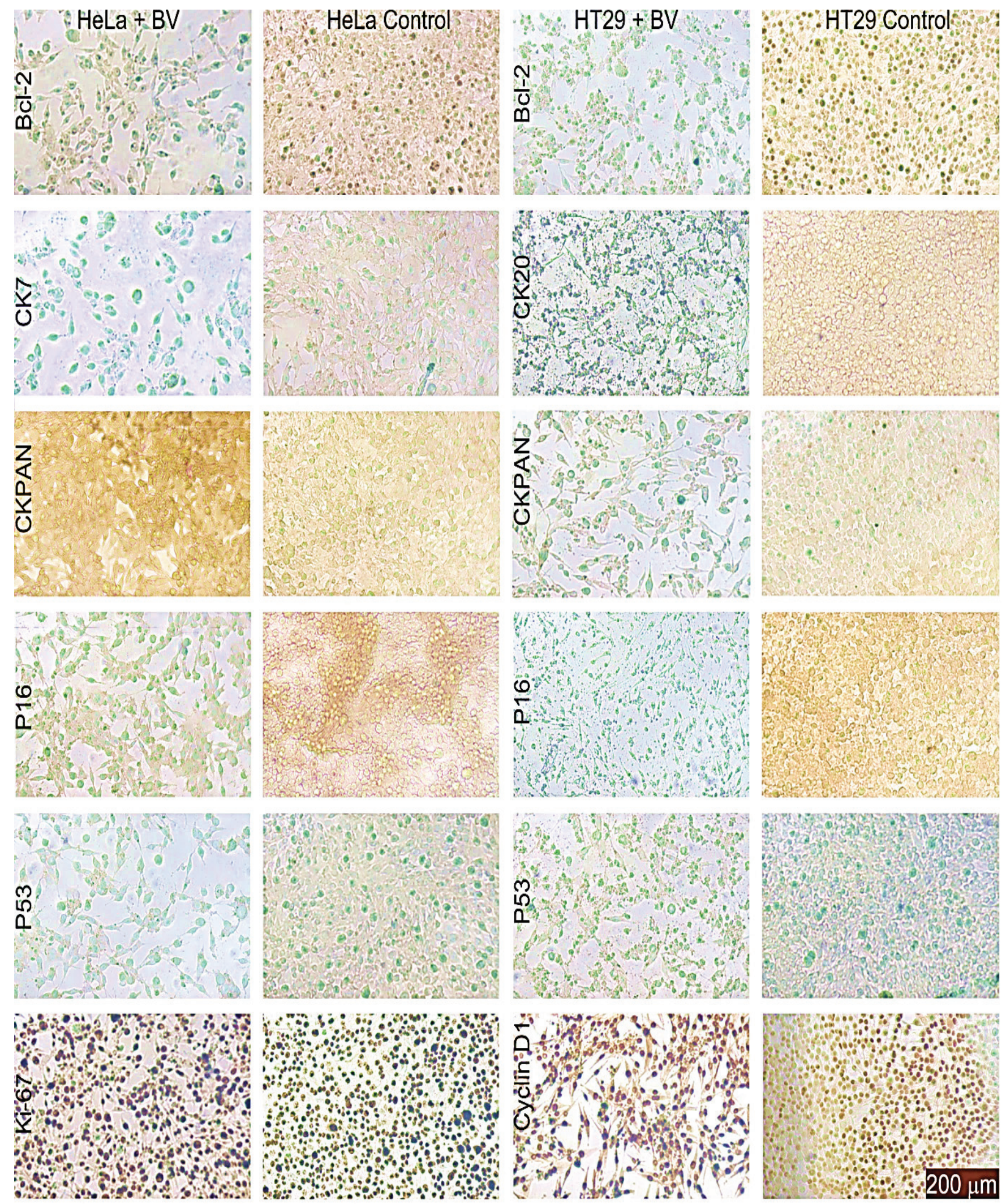

Figure 3. Representative images of the cells examined by immunohistochemical staining for functional protein group (Bcl-2, P16, P53, Cyclin D1, and Ki-67), and for marker protein group (CK7, CK20, and pan-CK). The specific signals are shown as brown staining. Bars are $200 \mu \mathrm{m}$. 
Table 1. Antimicrobial activity of BV affects the susceptibility of selected antimicrobial agents tested against the multidrug resistant human pathogens.

\begin{tabular}{llcclcc}
\hline Organism/ Resistant Type & Antimicrobials & $\mathrm{MIC}^{\mathrm{a}}$ & $\mathrm{S} / \mathrm{R}^{\mathrm{b}}$ & Antimicrobials $+\mathrm{BV}$ & $\mathrm{MIC}$ & $\mathrm{S} / \mathrm{R}$ \\
\hline & Ampicillin/Sulbactam & $>16 / 8$ & $\mathrm{R}$ & Ampicillin/Sulbactam & $>16 / 8$ & $\mathrm{R}$ \\
& Cefazolin & $>8$ & $\mathrm{R}$ & Cefazolin & $>8$ & $\mathrm{R}$ \\
& Gentamicin & $>8$ & $\mathrm{R}$ & Gentamicin & $\leq 2$ & $\mathrm{~S}$ \\
& Ceftazidime & $>16$ & $\mathrm{R}$ & Ceftazidime & $\leq 0.5$ & $\mathrm{~S}$ \\
Escherichia coli / ESBL & Piperacillin/Tazobactam & $>64 / 4$ & $\mathrm{R}$ & Piperacillin/Tazobactam & $\leq 4 / 4$ & $\mathrm{~S}$ \\
& Imipenem & $\leq 0.5$ & $\mathrm{~S}$ & Imipenem & $\leq 0.5$ & $\mathrm{~S}$ \\
& Cefotaxime/Clavulanate & $<9$ & $\mathrm{~S}$ & Cefotaxime/Clavulanate & $<9$ & $\mathrm{~S}$ \\
& Ceftazidime/Clavulanate & $<9$ & $\mathrm{~S}$ & Ceftazidime/Clavulanate & $<9$ & $\mathrm{~S}$ \\
& Ceftriaxone/Clavulanate & $<9$ & $\mathrm{~S}$ & Ceftriaxone/Clavulanate & $<9$ & $\mathrm{~S}$ \\
\hline & Penicillin & $>1$ & $\mathrm{R}$ & Penicillin & $>1$ & $\mathrm{R}$ \\
& Ampicillin & $>8$ & $\mathrm{R}$ & Ampicillin & $>8$ & $\mathrm{R}$ \\
& Erythromycin & $>4$ & $\mathrm{R}$ & Erythromycin & $>4$ & $\mathrm{R}$ \\
& Clindamycin & $>2$ & $\mathrm{R}$ & Clindamycin & $\leq .25$ & $\mathrm{~S}$ \\
& Vancomycin & $>16$ & $\mathrm{R}$ & Vancomycin & $\leq 1$ & $\mathrm{~S}$ \\
& Daptomycin & 1 & $\mathrm{~S}$ & Daptomycin & 1 & $\mathrm{~S}$ \\
& Linezolid & 2 & $\mathrm{~S}$ & Linezolid & 2 & $\mathrm{~S}$ \\
\hline
\end{tabular}

${ }^{a}$ MIC determined according CLSI (2014) (19) recommendations, ( $\left.\mu \mathrm{g} / \mathrm{mL}\right)$

bS/R, Susceptible/Resistant

only on HeLa, C6 and HT29 tumor cell lines but also on Vero cells. BV seems more toxic than the control drug 5FU at subtoxic concentrations $(\mathrm{P}<0.05)$ (Figure 1A). These data suggest that BV may not be a good candidate as an anticancer agent. Although previous reports have emphasized the antitumor effects of BV $(21,22)$, our results suggest that BV is highly toxic to nontumorigenic cells as well.

We also focused on the potential active ingredient that BV may contain. Heat treatment of BV significantly reduced its antiproliferative activity (Figure 1A), which indicates the probability that at least one active ingredient of $\mathrm{BV}$ is a protein. In fact, melittin, a major component of BV has been shown to possess greater antitumor activity $(1,22)$. However, as reported earlier $(23,24)$, other components of the BV may be responsible for the biological activities of it.

According to the wound-closure assay results, BV inhibited HeLa cell migration at $\mathrm{IC}_{30}$ concentration (Figure 2A), suggesting that it might have antimetastatic potential. However, this result was not consistent with previous studies that BV stimulated human epidermal keratinocyte (HEK) migration and induced melanocyte dendricity and migration through $\mathrm{PLA}_{2}$ activation at sub-toxic concentration (25, 26). Furthermore, HeLa cells pretreated with BV did not proliferate in BV-free fresh cell culture medium (Data not shown), indicating the antiproliferative effect of $\mathrm{BV}$ is irreversible. To our knowledge, this information was described for the first time.

In this study, we have investigated whether the mechanism of the antiproliferative activity of BV involves in apoptosis. TUNEL (Figure 1C) and DNA laddering (Figure 1D) assays results showed that $\mathrm{BV}$ induced DNA fragmentation in cells, so it is indeed, the antiproliferative activity of BV involves induction of apoptosis. Although the apoptotic potential of BV has been previously documented (27), the effect on the near normal cells was unclear. Overall, our results suggest that BV displays its pharmacological effects via induction of apoptotic pathway rather than necrosis. BV significantly affected the morphology of treated cells and caused cell shrinkage, apoptotic body formation, loss of astrocyte-like and fibroblast-like appearance of the cells. Eventually, they detached from the plate and broke up into small pieces at higher concentrations.

We have also tested whether the antiproliferative activity of BV involves inhibition of DNA topoisomerase. DNA topoisomerase I inhibition assay showed that BV did not inhibit DNA laddering activity of DNA topoisomerase I (Figure 2B). This suggests that the BV suppresses cell proliferation using another pathway apart from the suppression of DNA topoisomerase I. 
Moreover, we have investigated the molecular mechanism of action of BV by determining the level of expression of several proteins in cells using immunohistochemistry. Immunohistochemical staining of the BV treated cell showed increased P16 levels indicating confirming its antiproliferative activity. BV caused decreased expression of Bcl-2, Ki-67, Cyclin D1, and P53 in HeLa and HT29 cells, indicating the apoptotic and apoptosis-promoting effects of $\mathrm{BV}$ (Figure 3). BV-induced increases in the $\mathrm{Bax} / \mathrm{Bcl}-2$ ratio were also reported in other cancer cells, including TSGH8301, A549 and NCI-H460 cells $(8,28)$. Similar observations are reported in HL60 cells undergoing BV-induced apoptosis (29). In addition, our findings showed that epithelial markers such as CK7, CK20, and pan-CK downregulated in HeLa cells, indicating differentiation of the cancer cells into apoptotic cells. Interestingly, in contrast to HeLa cells, pan-CK expression are suppressed in BV treated HT29 cells. However, the precise mechanism for the inhibition of epithelial cell markers such as CK7, CK20, and pan-CK in cancer cells is not clear. We have tested the antibacterial effect of BV on MDRP. Results showed that in contrast to treatment with antibiotics alone, antibiotics supplemented with BV significantly reduced the growth of the MDRP (Table 1). The antimicrobial activity of BV was documented on both Gramnegative and Gram-positive bacteria including Streptococcus salivarius, Lactobacillus casei, and Enterococcus faecalis (30). However, the antibacterial effect of BV on MDRP (ESBL producing Escherichia coli and VRE Enterococcus faecium) was defined for the first time. Therefore, this is the only study reporting the antibacterial effect of BV+antibiotics combination. It is suggested that BV may be used as an effective supplement in antibiotics for the treatment of MDRP however further evaluations require for clarification.
Furthermore, the antibiotics+BV combination therapy killed ESBL producing and VRE bacteria as compared to cells treated with antibiotics alone. However, the mechanism of antibacterial activity of BV+antibiotics combination is not known yet.

Although there have been numerous studies on the effects of BV on various maladies (31), a few have studied their effects on colon, cervix, and glioma cells. Furthermore, there are no studies examining the effect of BV on human multidrug resistant pathogens resistant to standard antibiotics. These findings provide important preliminary data for the use of BV against maladies and suggest a new route for enhancing efficacy and reducing toxicity by optimizing combinations of BV with chemotherapeutics. The results of this study support the efficacy of BV as an anticancer agent for cervical and colon cancer by using a potential adjuvant treatment to current chemotherapeutic agents used in the treatment of both cancer type. This study may also offer an alternative strategy for development of potential antineoplastic or antimicrobial therapies against cancerous and multidrug resistant bacteria. In conclusion, our results showed that BV possesses strong antiproliferative and cytotoxic activities against various tumor cells and nontumorigenic cells through inducing apoptosis and inhibit MDRP when used with antibiotics.

\section{Acknowledgments}

This study was supported by a grant (BAP 2014/23) from Gaziosmanpasa University, Scientific Research Projects Commission. The authors thank to Fatih Çüycü for his technical assistance for IHC.

\section{ÖZ}

Arı zehri kanser dahil çeşitli hastalıklar için bir apiterapi aracı olarak önerilmektedir. Ancak, arı zehrinin etki mekanizması ve tümörojenik ve tümörojenik olmayan hücreler üzerindeki toksisitesi çok fazla anlaşılamamıștır. Biz burada bal arısı (Apis mellifera L.) zehrinin tümörojenik olmayan, tümörojenik olan kanser hücrelerive Genişlemiş Spektrumlu Beta Laktamaz üreten Escherichia coli and Vankomisin-dirençli Enterococcus faecium gibi çoklu dirençli patojenler (MDRP) üzerinde antiproliferatif, sitotoksik ve antibakteriyel aktivitesini araştırdık. Arı zehri uygulaması önemli antiproliferatif, sitotoksik ve antibakteriyel aktivite göstermiştir. Bizim sonuçlarımız arı zehrinin sadece kanser hücrelerine değil nontümörojenik hücre hattına da toksik olduğunu göstermektedir. Biz ayrıca etki mekanizmasını araştırdığımız arı zehrinin apoptozisi işaret eden genomik DNA kırılmasına ve hücre göçü inhibisyonuna neden olduğunu gördük. İmmünokimyasal çalışmalar arı zehrinin Bcl-2 ve P16 ifadelerinde azalmaya neden olduğu göstermiştir. Arı zehri test edilen bazı çoklu dirençli bakterilere karşı antimikrobiyal aktivite göstermiştir. Bizim sonuçlarımız malignensilerin tedavisi için arı zehrinin klinik değerlendirilmesinin normal hücrelere karşı toksik etkisine bağlı olarak yeniden değerlendirilmesine ihtiyaç olduğunu göstermektedir.

Anahtar Kelimeler: Apis mellifera arı zehiri; Antiproliferatif aktivite; Antibakteriyel etkinlik; sitotoksik aktivite 


\section{References}

1. Son DJ, Lee JW, Lee YH, Song HS, Lee CK, Hong JT. Therapeutic application of anti-arthritis, pain-releasing, and anti-cancer effects of bee venom and its constituent compounds. Pharmacol Ther 2007; 115: 246-70.

2. Hider RC. Honeybee venom: A rich source of pharmacologically active peptides. Endeavour 1988; 12: 60-5.

3. Garaj-Vrhovac V, Gajski G. Evaluation of the cytogenetic status of human lymphocytes after exposure to a high concentration of bee venom in vitro. Arh Hig Rada Toksikol 2009; 60: 27-34.

4. Gajski G, Garaj-Vrhovac V. Bee venom induced cytogenetic damage and decreased cell viability in human white blood cells after treatment in vitro: a multi-biomarker approach. Environ Toxicol Pharmacol 2011; 32: 201-11.

5. Cherniack EP. Bugs as drugs, Part 1: Insects: the "new" alternative medicine for the 21st century? Altern Med Rev 2010; 15: 124-35.

6. Orsolic N. Bee venom in cancer therapy. Cancer Metastasis Rev 2012; 31: 173-94.

7. Hong SJ, Rim GS, Yang HI, Yin CS, Koh HG, Jang MH, et al. Bee venom induces apoptosis through caspase-3 activation in synovial fibroblasts of patients with rheumatoid arthritis. Toxicon 2005; 46: 39-45.

8. Ip SW, Chu YL, Yu CS, Chen PY, Ho HC, Yang JS, Huang HY, Chueh FS, Lai TY, Chung JG. Bee venom induces apoptosis through intracellular $\mathrm{Ca} 2+$-modulated intrinsic death pathway in human bladder cancer cells. Int J Urol 2012; 19 : 61-70.

9. Ip SW, Liao SS, Lin SY, Lin JP, Yang JS, Lin ML, Chen GW, Lu HF, Lin MW, Han SM, Chung JG.The role of mitochondria in bee venom-induced apoptosis in human breast cancer MCF7 cells. In Vivo 2008; 22: 237-45.

10. Tu WC, Wu CC, Hsieh HL, Chen CY, Hsu SL. Honeybee venom induces calcium-dependent but caspase-independent apoptotic cell death in human melanoma A2058 cells. Toxicon 2008; 52: 318-29.

11. Moon DO, Park SY, Choi YH, Kim ND, Lee C, Kim GY. Melittin induces Bcl-2 and caspase-3-dependent apoptosis through downregulation of Akt phosphorylation in human leukemic U937 cells. Toxicon 2008; 51: 112-20.

12. Son DJ, Ha SJ, Song HS, Lim Y, Yun YP, Lee JW, et al. Melittin inhibits vascular smooth muscle cell proliferation through induction of apoptosis via suppression of nuclear factorkappaB and Akt activation and enhancement of apoptotic protein expression. J Pharmacol Exp Ther 2006; 317: 627-34.

13. Cho HJ, Jeong YJ, Park KK, Park YY, Chung IK, Lee KG, et al. Bee venom suppresses PMA-mediated MMP-9 gene activation via JNK/p38 and NF-kappaB-dependent mechanisms. J Ethnopharmacol 2010; 127: 662-8.

14. Hamedani M, Vatanpour H, Saadat F, Reza Khorramizaheh M, Mirshafiey A. Bee venom, immunostimulant or immunosuppressor? Insight into the effect on matrix metalloproteinases and interferons. Immunopharmacol Immunotoxicol 2005; 27: 671-81.

15. Jeong YJ, Choi Y, Shin JM, Cho HJ, Kang JH, Park KK, et al. Melittin suppresses EGF-induced cell motility and invasion by inhibiting PI3K/Akt/mTOR signaling pathway in breast cancer cells. Food Chem Toxicol 2014; 68: 218-25.
16. Hu H, Chen D, Li Y, Zhang X. Effect of polypeptides in bee venom on growth inhibition and apoptosis induction of the human hepatoma cell line SMMC-7721 in-vitro and Balb/c nude mice in-vivo. J Pharm Pharmacol 2006; 58: 83-9.

17. Aydin A, Korkmaz N, Tekin S, Karadag A. Anticancer activities and mechanism of action of 2 novel metal complexes, C16H34N8O5Ag2Cd and C11H16N7O2Ag3Ni. Turk J Biol 2014; 38: 948-55.

18. Gong J, Traganos F, Darzynkiewicz Z. A selective procedure for DNA extraction from apoptotic cells applicable for gel electrophoresis and flow cytometry. Anal Biochem 1994; 218 : 314-9.

19. Wayne, PA. Clinical and Laboratory Standards Institute. Clinical and Laboratory Standards Institute. 2014. Performance standards for antimicrobial susceptibility testing; 24th informational supplement. CLSI document M100-S24.

20. Heinen TE, da Veiga AB. Arthropod venoms and cancer. Toxicon 2011; 57: 497-511.

21. Abd-Elhakim YM, Khalil SR, Awad A, Al-Ayadhi LY. Combined cytogenotoxic effects of bee venom and bleomycin on rat lymphocytes: An in vitro study. Biomed Res Int 2014; 2014: 173903.

22. Ownby CL, Powell JR, Jiang MS, Fletcher JE. Melittin and phospholipase A2 from bee (Apis mellifera) venom cause necrosis of murine skeletal muscle in vivo. Toxicon 1997; 35 : 67-80.

23. Dotimas EM, Hamid KR, Hider RC, Ragnarsson U. Isolation and structure analysis of bee venom mast cell degranulating peptide. Biochim Biophys Acta 1987; 911: 285-93.

24. Habermann E. Bee and wasp venoms. Science 1972; 177:314-22.

25. Han SM, Park KK, Nicholls YM, Macfarlane N, Duncan G. Effects of honeybee (Apis mellifera) venom on keratinocyte migration in vitro. Pharmacogn Mag 2013; 9: 220-6.

26. Jeon S, Kim NH, Koo BS, Lee HJ, Lee AY. Bee venom stimulates human melanocyte proliferation, melanogenesis, dendricity and migration. Exp Mol Med 2007; 39: 603-13.

27. Zheng J, Lee HL, Ham YW, Song HS, Song MJ, Hong JT. Anticancer effect of bee venom on colon cancer cell growth by activation of death receptors and inhibition of nuclear factor kappa B. Oncotarget 2015; 6: 44437-51.

28. Choi KE, Hwang CJ, Gu SM, Park MH, Kim JH, Park JH, et al. Cancer cell growth inhibitory effect of bee venom via increase of death receptor 3 expression and inactivation of NF-kappa B in NSCLC cells. Toxins (Basel) 2014; 6: 2210-28.

29. Lee YJ, Kang SJ, Kim BM, Kim YJ, Woo HD, Chung HW. Cytotoxicity of honeybee (Apis mellifera) venom in normal human lymphocytes and HL-60 cells. Chem Biol Interact 2007; 169: 189-97.

30. Leandro LF, Mendes CA, Casemiro LA, Vinholis AH, Cunha WR, de Almeida R, et al. Antimicrobial activity of apitoxin, melittin and phospholipase A(2) of honey bee (Apis mellifera) venom against oral pathogens. An Acad Bras Cienc 2015; 87: 147-55.

31. Slaninová J, Mlsová V, Kroupová $H$, Alán L, Tůmová $T$, Monincová L, Borovičková L, Fučík V, Ceřovský V. Toxicity study of antimicrobial peptides from wild bee venom and their analogs toward mammalian normal and cancer cells. Peptides 2012; 33: 18-26. 